\title{
SHAREHOLDER WEALTH GAINS THROUGH BETTER CORPORATE GOVERNANCE - The Case of European LBO-Transactions
}

\section{Christian Andres, André Betzer and Charlie Weir ${ }^{*}$}

\begin{abstract}
We examine shareholder wealth effects in a heterogeneous sample of 115 European leveraged going private transactions from 1997 to 2005. Average abnormal returns as reaction to the LBO announcement amount to $24.20 \%$. In cross-sectional regressions we find that these value gains can largely be attributed to differences in corporate governance: on a macro level, abnormal returns for pre-LBO shareholders are larger in countries with a poor protection of minority shareholders. On a firm level, companies with a high pre-LBO free float and comparatively weak monitoring by shareholders tend to show high abnormal returns. Furthermore, companies that are undervalued with respect to an industry peer-group exhibit higher announcement returns, indicating that agency conflicts and/or market inefficiencies can serve as an explanation.
\end{abstract}

JEL Classification: G 14, G 32, G 34

Keywords: $\quad$ LBOs, Corporate Governance, Agency Theory, Event Study

Acknowledgements We would like to thank Erik Theissen and two anonymous referees for helpful and constructive comments.

${ }^{*}$ The first and second authors are from the Chair of Finance and Banking, University of Bonn. The third author is from the Aberdeen Business School, The Robert Gordon University.

Adress for correspondence: Christian Andres and André Betzer, University of Bonn, Department of Economics / BWL1, Adenauerallee 24-42, 53113 Bonn, Germany.

e-mail: andres@uni-bonn.de, andre.betzer@uni-bonn.de, c.weir@rgu.ac.uk 


\title{
SHAREHOLDER WEALTH GAINS THROUGH BETTER CORPORATE GOVERNANCE - The Case of European LBO-Transactions
}

\begin{abstract}
We examine shareholder wealth effects in a heterogeneous sample of 115 European leveraged going private transactions from 1997 to 2005. Average abnormal returns as reaction to the LBO announcement amount to $24.20 \%$. In cross-sectional regressions we find that these value gains can largely be attributed to differences in corporate governance: on a macro level, abnormal returns for pre-LBO shareholders are larger in countries with a poor protection of minority shareholders. On a firm level, companies with a high pre-LBO free float and comparatively weak monitoring by shareholders tend to show high abnormal returns. Furthermore, companies that are undervalued with respect to an industry peer-group exhibit higher announcement returns, indicating that agency conflicts and/or market inefficiencies can serve as an explanation.
\end{abstract}

JEL Classification: G 14, G 32, G 34

Keywords: $\quad$ LBOs, Corporate Governance, Agency Theory, Event Study 
The late 1990s and early 2000s saw a large increase in the number, and value, of leveraged going private buy-outs (LBOs) in Continental Europe and in the UK (CMBOR 2005). This increase in LBO activity had earlier been experienced in the US in the 1980s (OPLER and TITMAN 1993). US evidence reveals positive and significant returns to the firm's shareholders upon announcement of an LBO. For example, DE ANGELO, DE ANGELO and RICE (1984) find a cumulative average return (CAR) of 28.05\%, LEHN and POULSEN (1989) of 19.90\% and TRAVLOS and CORNETT (1993) of 19.89\%over a 21-day event window ranging from 10 days before to 10 days after the announcement of and LBO transaction $[-10 ;+10]$ repectively. Given the significant returns reported in the US, it is important to assess the extent to which these gains are replicated by European LBOs.

In an LBO transaction a private equity investor, the former management of the company and an LBO fund which is managed by the private equity investor take a firm private by purchasing its outstanding shares. The emerging new shareholder structure aims to mitigate potential agency problems between management and shareholders. Subsequent to the takeover the shares are de-listed from the stock exchange. The flip side of the concentrated shareholder structure is that the financing of this transaction is only realizable with a significant amount of debt. In the $1980 \mathrm{~s}$, leverage ratios were 20 to 1 on average. ${ }^{1}$ As a result, the new highly leveraged company has to bear an increased financial risk. It commits itself to pay out a significant amount of possible future cash flows to debt holders.

This study investigates the wealth effects of leveraged going private transactions by applying event study methodology in a pan-European context. So far, LBO research in the European markets is restricted to the UK. For example, WEIR, LAING and WRIGHT (2005a and 2005b) were the first to analyse the determinants of going private transactions in the UK. Their findings identify poor stock price performance, bad governance structures and low growth opportunities as important factors in the probability of companies going private. In terms of shareholder wealth effects, RENNEBOOG, SIMONS and WRIGHT (2005) investigate the impact of LBO announcements from 1997 to 2003 in the UK market. They find abnormal returns to pre-LBO shareholders of about $29.28 \%[-40 ;+40]$ resulting from better use of tax shields, bad stock price performance in the past and incentive realignment. 
Corporate governance has been shown to be one of the primary determinants of shareholder wealth gains in previous work on the US and UK. According to TIROLE (2006) the leveraged buyout transaction as governance instrument of the market of corporate control creates "a new and superior form of corporate governance". Hence gains generated by an LBO may be indicative of ineffective corporate governance mechanisms. This study therefore analyses the impact of a number of corporate governance mechanisms on short-term announcement returns associated with European LBOs. These mechanisms relate to free cash flows, shareholder monitoring, shareholder protection, undervaluation and the market for corporate control. We develop hypotheses which test the relationship between governance mechanisms and the extent of abnormal returns generated by an LBO announcement.

An analysis focusing on the UK and Continental European LBO market is therefore important for the following reasons. First, unlike the homogeneous US capital market, the European market is heterogeneous in terms of capital market culture and development, legal framework and corporate governance standards. The most important difference lies in the composition of the shareholder structure. Most publicly traded companies in the US and the UK tend to be widely-held whereas the ownership structure of most Continental European companies exhibits a large, dominant shareholder (e.g. families or institutional shareholders) who exerts considerable control (FACCIO and LANG 2002). Second, the market for corporate control is less active and less developed in Continental Europe (FRANKS and MAYER 1990). Third, the protection of minority shareholders through binding corporate governance standards is also weak (LA PORTA et al. 1998).

Furthermore, LBOs tend to involve small firms, and small companies suffer from a lack of attention from financial analysts and investment trusts. ${ }^{2}$ For that reason, value enhancing measures by the incumbent management of those firms are disregarded by the financial market and the actual share price may not accurately reflect the intrinsic value of the company. There is anecdotal evidence (e.g. Eskimuir Properties plc in 1998) that private equity investors purchase those companies and take them private.

The above-mentioned empirical facts imply that those Continental European companies with an atomistic shareholder structure will suffer more agency problems than their US and UK counterparts because their (dispersed) shareholders can neither rely on an effective monitoring nor on a good corporate governance regime. Underpinning this is the argument 
that a less concentrated ownership structure harms firm value because of ineffective monitoring, (SHLEIFER and VISHNY (1986) and ADMATI, PFLEIDERER and ZECHNER (1994)).

We find that the announcement of an LBO generates significant positive abnormal returns of $11.94 \%$ on the day of the announcement. We also find cumulative average abnormal returns (CARs) of $24.20 \%[-30 ;+30]^{3}$. Relating the abnormal returns to different explanatory variables in several cross-sectional regressions we find that cumulative abnormal returns are positively related to the extent of free float, which indicates poorer monitoring. We also find that CARs are higher the lesser the extent of shareholder protection as measured by an AntiDirector-Rights Index. CARs are also higher the greater the relative decline in share price prior to the LBO. Lower valuations also produce higher CARs. Our results show that weak monitoring by shareholders and weak shareholder protection lead to significant CARs. The analysis therefore suggests that corporate governance mechanisms are important factors in explaining the short term gains generated by European LBOs.

The rest of the paper is organized as follows. Section II summarizes the prior empirical research on LBOs and defines the variables and proxies used in the cross-sectional analysis. Section III focuses on the data used in the analysis and presents various descriptive statistics. In Section IV the test design and the results of the event study are outlined. Section V presents the results of our cross-sectional regression and finally, Section VI draws some conclusions.

\section{Possible Sources Of Abnormal Returns And Testable Hypotheses}

Evidence on abnormal returns can be found in different papers examining the US market. In an early study on shareholder returns in LBO transactions DE ANGELO, DE ANGELO and RICE (1984) found an abnormal cumulative return of $30.4 \%$ in a 41 day event window [40;0]. Depending on the length of the event window the cumulative abnormal returns of other previous studies on the US market are in a range of $13 \%$ to $37.9 \%$. An overview of these studies is shown in Table I.

[Insert Table I about here]

By conducting regressions of the abnormal returns on various explanatory variables, some studies for the US market examined the factors and theories explaining the stock price 
reaction to the buyout announcements and the gains for pre-LBO shareholders. These theories and new explanations that account for distinctive features of the European market are discussed in the following paragraphs. Furthermore, we derive several hypotheses in order to test the explanatory power of these theories.

It should be pointed out that abnormal returns are a function of the premiums ${ }^{4}$ offered by the bidding financial investor and the probability of success ${ }^{5}$ the market assigns to the respective bid. Formally, that is

Stock Price at announcement date $=$ (expected tender offer price) * (success probability) + (price without LBO) * (failure probability).

The following explanations relate to both: the premiums as well as the perceived probability of the takeover actually being successful.

\section{II.1 Corporate Governance}

\section{Mitigation Of Agency Costs Of Equity}

The mitigation of agency costs of equity is one of the most often cited sources for shareholders' gains in LBOs. These agency costs arise when principals (shareholders) hire agents (external managers) to run their company and include for instance contract costs and the costs of monitoring between principals and agents (JENSEN and MECKLING 1976).

JENSEN (1986) argues that agency problems are particularly severe for mature companies - like most of the companies in our sample - with few or no positive net present value investment opportunities and thus large free cash flows. Thus the free cash flow hypothesis argues that managers tend to waste these cash flows instead of distributing them to shareholders (JENSEN 1986, 1989).

The conflict of interests between shareholders and managers over the distribution of free cash flows can be mitigated through an LBO. As a consequence of the substantial debt servicing costs incurred as a result of the LBO, the amount of free cash under management 
control is simply reduced and thus the potential to misuse these funds decreased. The heavy debt burden further disciplines managers as they are more financially responsible due to the risk of loan default (JENSEN 1989 and HITE and VETSUYPENS 1989).

Empirical results presented by LEHN and POULSEN (1989) are consistent with Jensen's agency costs of free cash flow hypothesis as their findings indicate a strong positive correlation between premiums and free cash flows - especially for companies with low preLBO management equity holdings. Our corresponding hypothesis is:

H1 (FCF): Abnormal returns are higher for companies with a high free cash flow (FCF).

We employ the free cash flow definition used by LEHN and POULSEN (1989). Free cash flow is defined as operating income before amortization and depreciation minus taxes, interest expenses and dividends in the year before the buyout announcement. The free cash flows are then divided by the companies' sales of the same fiscal year. Accordingly, this variable tests whether companies with a higher potential to misuse their cash flow show higher abnormal returns. The expected coefficient for $F C F$ is thus positive.

To a certain extent the problem of agency costs of equity should be mitigated by monitoring. In the case of public companies, however, the free rider problem prevents shareholders - especially those with small holdings - from sacrificing their resources to monitor the management (AMIHUD 1989 and JENSEN and MURPHY 1990). There are a number of reasons why the organizational changes associated with an LBO are expected to mitigate these problems.

First, management becomes a significant investor in the company and will - due to the alignment of interests between owners and managers - refrain from value-destroying actions (KAPLAN 1989). Moreover, management will actively seek to increase value by increasing operating efficiency.

Second, management is closely monitored by professionals - "active investors" (JENSEN 1989) - who can efficiently execute this task and fully benefit from the effect. Due to the weak minority shareholder protection in Europe (LA PORTA et al. 1998) the problem of poor 
monitoring in widely-held corporations is aggravated in our sample. Depending on the quality of the corporate governance system, entrenched managers may be tempted to misuse excess liquidity for their private benefit. Under these circumstances an efficient control of management can only be ensured by active shareholders with a substantial equity stake.

However, a possible counter-argument concerning the effect of free-riding in takeover situations is raised by GROSSMAN and HART (1980). They found that shareholders in an atomistic shareholder structure do not want to tender their shares to the bidder whenever they assume that the intrinsic value of the firm is higher than the offer price. This behaviour can be explained by the fact that small shareholders are not pivotal in the success of the takeover and therefore, they prefer to wait until the new acquirer has increased the value of the firm. Following this argument, the probability of conducting an LBO transaction (and thus the expected share price reaction) should be lower for companies with an atomistic shareholder structure.

Despite this argument we expect the possible value enhancements through a more efficient shareholder structure and better monitoring to dominate this effect and hypothesize:

H2 (monitoring): A higher free float leads to a higher abnormal return.

The free float is determined by subtracting all shareholdings of investors with an interest of more than $5 \%{ }^{6}$ of the share capital from the total share capital. These shareholdings are based on the last annual financial statement published prior to the LBO announcement. In contrast to common stock exchange free float-definitions, ${ }^{7}$ shareholdings of mutual funds are considered not to be free float as soon as they are in excess of 5\%. It can be argued that these sizeable shareholdings give the fund a certain degree of influence. Even though it may be unlikely that fund managers with large shareholdings will actively interfere, they will surely have and use the opportunity to directly approach management to express their views. The expected coefficient for monitoring is therefore positive.

Various empirical studies show that managerial ownership has a significant influence on firm performance (MORCK et al. 1988 and MEHRAN 1995). In addition, BEINER et al. (2006) find empirical evidence for the incentive-alignment hypothesis (JENSEN and 
MECKLING 1976) and argue that managerial stockholdings can be seen as an important corporate governance mechanism. Managerial ownership may also be a substitute for other governance mechanisms such as the extent of non-executive director representation, PEASNELL, POPE and YOUNG (2003). ${ }^{8}$ Therefore, we use the percentage of managerial ownership before the LBO announcement as an explanatory variable. If managers are large shareholders even before the LBO, agency-problems should be less pronounced in these companies. As a consequence, we expect lower efficiency gains after the LBO.

H3 (stake): Higher managerial ownership before the LBO leads to smaller abnormal returns.

However, a number of studies document a non-linear relationship between managerial stockholdings and firm performance, suggesting that managers might be entrenched at higher ownership stakes, for example, MORCK et al. (1988) and MCCONNELL and SERVAES (1990) for the US and WEIR, LAING and MCKNIGHT (2002) for the UK. We therefore control for a possible nonlinear relationship by including a squared term.

$H 4\left(\right.$ stake $\left.^{2}\right)$ : The relationship between managerial equity stake and abnormal returns is nonlinear.

Based on our data on blockholdings, we only employ managerial shareholdings in excess of $5 \%$ in our analysis because of data restrictions. The expected coefficient of the variable stake is negative while the coefficient of $s_{a k e}{ }^{2}$ is expected to be positive.

\section{Corporate Governance Regime}

LA PORTA et al. (1998) argue that the stock price of companies is positively influenced by a higher degree of legal protection of minority shareholders in the relevant country. This means that in countries with a better legal protection of shareholders' rights and interests, outside investors are willing to pay more for financial assets. In general, LA PORTA et al. (1998) distinguish between Common and Civil Law with the former offering greater investor protection and the latter providing weaker investor protection. Consequently they observe a higher stock price valuation in countries whose legal system is based on Common Law. Therefore a buyout announcement should result in a higher price increase in Civil Law 
countries. After going private, the protection of minority shareholders is no longer required and the justification for the discount in bad governance regimes disappears.

H5 (law): Abnormal returns are higher in Continental Europe.

In our sample, the distinction between Common and Civil Law countries leads to a separation between UK-based companies on the one hand and Continental European firms on the other hand. We use a dummy variable to test for the influence of shareholder protection with " 0 " for Continental Europe, a system based on civil law, and " 1 " representing the UK where the system is based on common law. The expected coefficient for law is therefore negative.

In order to grasp the differences between the individual corporate governance regimes in more detail we also employ the so-called Anti-Director-Rights-Index (ADR-Index) developed by LA PORTA et al. (1998). The ADR-Index rates the country's degree of shareholder right protection based on different criteria and ranges from 0 (Belgium, where no criterion is satisfied) to 5 (for example, UK, where all criteria are satisfied), meaning that a better protection of shareholders' interests is associated with a higher index value. ${ }^{9}$ It includes inter alia the one share one vote principle and the possibility of shareholders to vote at the stockholder's meeting via Email or not. In line with the rationale concerning Civil vs. Common Law countries, higher stock price reactions are therefore expected in countries with low index values.

H6 (ADR): A lower ADR-index value leads to higher abnormal returns.

For both variables, country affiliation is based upon the firms' headquarters. As stated above, the ADR index ranges from " 0 " to " 5 ". The expected coefficient is negative.

\section{II.2 Market Inefficiencies}

So far, the rationale for shareholder gains in LBO transactions is based on the assumption that the market is semi-strong form efficient in FAMA's $(1970,1991)$ sense. ${ }^{10}$ In the presence of agency costs, the company might be valued correctly as the value incorporates all (public) 
information about these costs and managerial (mis-) behaviour. In the presence of information asymmetry the market value might reflect all publicly available information, but not management's private information about the future prospects of the company.

The possibility of conveying favourable information to market participants is often limited for small companies because they are usually not adequately covered by analysts and the financial press. The resulting illiquidity is one reason why information is inadequately reflected in the share price. In this case, the semi-strong form efficiency is violated. It is not until the publication of the LBO announcement and thus an increasing public interest that the stock becomes more liquid and all relevant information is incorporated in the stock price. This effect shall be empirically examined by the following hypothesis:

H7 (size): Abnormal returns are higher for smaller firms.

Size is neasured by the natural log of total assets as stated in the last annual financial statement prior to the buyout announcement. The expected coefficient is negative.

However, even if the firm's stock is actively traded and sufficient analysis has been undertaken, noise traders could ignore available information and act in a manner that brings about a valuation that does not reflect the stock's intrinsic value (DE LONG, SHLEIFER, SUMMERS and WALDMANN 1990).

Furthermore, the above-mentioned market inefficiencies alongside with other psychological or technical market movements might lead to an unjustified devaluation of a company's stock. Dissatisfied managers who see the market value of their company slumping and find no way to communicate their beliefs about the 'fair' value to other market participants may seek a way out of this situation by attempting a buyout. ${ }^{11}$ For example, WEIR, LAING and WRIGHT (2005b) find that the management of firms going private perceive that the company has been undervalued by the market. On the other hand, active private equity investors can find appropriate buyout 'candidates' by looking for undervalued companies: 
H8 (price): The more the market-adjusted share price declined during the 2 years prior to the announcement, the higher the abnormal return.

The numerator of the variable price is defined as the ratio of the closing market price two months prior to the LBO announcement divided by the average price, measured over 500 trading days counting backwards from two months prior to the LBO announcement. In order to exclude market movements we divide this figure by the equivalent ratio of the Dow Jones 600, a European market index covering seventeen countries. The expected coefficient for price is negative.

It is important to notice that abnormal returns arising from the elimination of market inefficiencies and from the mitigation of agency problems should not be confused. In the empirical literature, the finding that some sort of valuation variable (e.g. P/E-ratios) is significantly related to the LBO announcement return is often interpreted as a sign for the mitigation of agency costs. ${ }^{12}$ However, it may also be a result of market inefficiency (violation of the semi-strong form efficient market hypothesis). Although the influences of these interpretations cannot be strictly separated they can be united under the following hypothesis:

H9 (P/E): The lower the companies' $\mathrm{P} /$ E-ratio compared to an industry peer group, the higher the abnormal return.

The P/E-ratios employed in this study are based on a mean of ten trading days, measured two months prior to the LBO announcement. By going two months backwards from the announcement date we want to exclude possible anticipation effects of the LBO that would bias the results. The $\mathrm{P} / \mathrm{E}$ variable is defined as the target's $\mathrm{P} / \mathrm{E}-\mathrm{ratio}$ divided by the peers' average $\mathrm{P} / \mathrm{E}$-ratio. The expected coefficient for $P / E$ is negative. 


\section{II.3 Winner's Curse}

Private equity firms might for some reason bid for a company in excess of its fair value. In this case, markets again are assumed to be semi-strong form efficient in the Fama sense and the share price is assumed to fully reflect the company's potential. An overpayment might occur in competitive bidding situations, when bidders are in "deal fever" and do not want to accept that their analysis, negotiations and due diligence have been in vain. Overpayment might also be a sign of the presence of the winner's curse effect in bidding contests.

KAPLAN (1989) found higher abnormal returns for LBOs with the involvement of a hostile third party. LOWENSTEIN (1985) as well as AMIHUD (1989) present results which show substantially higher premiums in cases of competition among bidders. One reason for this finding might be overpayment. The fact that LBO companies occasionally fail should be an indicator that private equity investors (and the management of the company) misjudge a company's future potential. We examine this argument by the following hypothesis:

H10 (contested): Abnormal returns are higher in buyouts with multiple bids.

The variable contested is a dummy that equals " 1 " if the successful LBO bid is a reaction to a previous buyout offer and " 0 " otherwise. The expected coefficient is positive.

\section{Data Sources And Descriptive Statistics}

The initial sample consists of a total of 225 successfully completed going private transactions of European companies from 1997 to 2005. The transactions are identified by searching the Bloomberg, Reuters and Wall Street Journal Europe databases. To be included in the final sample, transactions have to meet the following criteria:

(1) The company subject to an LBO had to be based in the European Union. ${ }^{13}$

(2) To qualify as "leveraged" transactions, the share of debt financing in the total transaction had to be at least $50 \%{ }^{14}$

(3) $100 \%$ of the target company's share capital is bought via tender offer. 
(4) The buyout had to be led by a private equity investor as opposed to wealthy individuals or strategic investors.

Out of the initial 225 transactions 118 transactions which meet the above requirements are identified. Two of these transactions are excluded as the target company experienced financial distress immediately prior to the LBO and one company is excluded due to a lack of reliable share price data, leaving a final sample of 115 LBOs. The announcement dates of these 115 LBOs are the days when the acquiring private equity firm released their offer price to preLBO shareholders. All quotes are closing prices of the main stock exchange of the country the respective company is based in. Share price and balance sheet data used in this study are taken from Datastream and Bloomberg databases.

\section{[Insert Table II about here]}

Panel A shows that the number of European LBOs increased significantly in the late $1990 \mathrm{~s}$ and fell in the early 2000s. However, as the comparison of average and median transaction values in Panel A Table II shows, the deal size increases from year to year in the sample period. This development reflects the fact that Private equity funds attract more and more funds in order to finance major deals like Jefferson Smurfit (deal value: 3.7 Billion $€$ ). The final column in Panel A shows that the value of LBO deals peaked in the years 1999 and 2000 but then fell back. In recent years, the value of deals has started to increase again. Panel B shows the relative importance of the UK in LBO transactions. In the first two years of the sample period, LBOs only took place in the UK, but from 1999 to 2005 the share of UK LBOs declined to $54 \%$. These numbers show the increasing importance of LBOs in Continental Europe.

\section{[Insert Table III about here]}

Table III presents various key statistics for the investigated companies and allows to identify certain particular features of LBO targets. LBOs experience relative price declines over the previous 500 trading days with the average Price value being 0.91 . They also have, on average, lower $\mathrm{P} / \mathrm{E}$ ratios that their peers, 0.90, and may therefore be regarded as undervalued and higher agency costs. The average free float is $50 \%$ and the free cash flow ratio is 0.07 . In terms of shareholder legal protection, $52 \%$ are covered by a common law system. The average 
investor protection index score, $\mathrm{ADR}$, is 3.92. We find that $7 \%$ of $\mathrm{LBOs}$ were the reaction to a previous buy-out offer. The average management stake is $8.6 \%$.

As the cross-sectional analysis requires some variables to be industry-adjusted, peer groups of five publicly listed competitors for each of the 115 companies are identified. The selection of the peer groups is based on the automatic Bloomberg peer group selection. Out of this selection, those five companies that are most comparable to the LBO company with respect to their operations and regional focus and in terms of size are included in the peer group. $^{15}$

\section{Event Study}

\section{IV.1 Empirical Design}

The abnormal returns for pre-LBO shareholders are determined in an event study. ${ }^{16}$ In our case the event is the LBO announcement, i.e. the proposed cash offer to shareholders published on newswires like Bloomberg. The abnormal returns $\left(\varepsilon_{i t}^{*}\right)$ of each company are computed as the difference between the observed return $R_{i t}$ and the expected return $\mathrm{E}\left(R_{i t / X t}\right)$, where $X_{t}$ is the conditioning information in the modelling of the expected return.

$$
\varepsilon_{i t}^{*}=\mathrm{R}_{\mathrm{it}}-\mathrm{E}\left[\mathrm{R}_{\mathrm{it}} \mid \mathrm{X}_{\mathrm{t}}\right]
$$

We use the constant mean return and the market model to calculate the daily abnormal returns. Both models are commonly used in event studies and should, according to BROWN and WARNER (1985), lead to similar results under certain conditions.

Formally, the constant mean return model is given by:

$$
\begin{array}{ll}
R_{i t}=\mu_{i}+\xi_{i t} & \\
\mathrm{E}\left[\xi_{i t}\right]=0 \quad \operatorname{Var}\left[\xi_{i t}\right]=\sigma_{\xi_{i}}^{2},
\end{array}
$$

where $\mu_{i}$ is the average return for security $i, R_{i t}$ is the return at time $\mathrm{t}$ and $\xi_{i t}$ is the disturbance term of the equation. 
The market model is given by:

$$
R_{i t}=\alpha_{i}+\beta_{i} R_{m t}+\varepsilon_{i t}
$$

$$
\mathrm{E}\left[\varepsilon_{i t}\right]=0 \quad \operatorname{Var}\left[\varepsilon_{i t}\right]=\sigma_{\varepsilon_{i}}^{2},
$$

where $R_{i t}$ and $R_{m t}$ are the returns of share $i$ and an index representing the market portfolio $m$ at time $t$, respectively. The coefficients $\alpha$ and $\beta$ are estimated by OLS with the estimation period being $t=-280$ to $t=-30$ relative to the announcement day. The event period ranges from $t=-30$ to $t=+30$ relative to the announcement day. In estimating the market model, we use the broad European Dow Jones STOXX 600 index to proxy for the market portfolio. The Dow Jones STOXX 600 index represents large, mid and small capitalisation companies across 17 countries of the European region. ${ }^{17}$

The more sophisticated market model removes the co-movement of the returns with the market. Therefore it reduces the variance of the abnormal returns which will lead to more precise results.

The average abnormal return on day $\mathrm{t}$ relative to the announcement date across a sample of $\mathrm{N}$ events can be be written as:

$$
\bar{\varepsilon}_{\mathrm{t}}^{*}=\frac{1}{\mathrm{~N}} \sum_{\mathrm{t}=\mathrm{T}_{1}}^{\mathrm{T}_{2}} \varepsilon_{\mathrm{it}}^{*} .
$$

The cumulated average abnormal return (CAR) over the interval $[a, b]$ is then given by:

$$
\mathrm{CAR}_{[\mathrm{a}, \mathrm{b}]}=\sum_{\mathrm{t}=\mathrm{a}}^{\mathrm{b}} \bar{\varepsilon}_{\mathrm{t}}^{*}
$$

After the calculation of the cumulative abnormal returns, we test their statistical significance using both a t-test and the non-parametric Corrado ${ }^{18}$ test. 


\section{IV.2 Results of the Event Study}

Table IV presents the event study results. The table reports daily abnormal returns for each day $\mathrm{t}$ of the event window and cumulative abnormal returns for event windows beginning on day -15 and ending on day $t=15 . t=0$ represents the day on which the LBO proposal was published.

\section{[Insert table IV about here]}

As can be seen from Table IV, the announcements of LBOs cause significant positive abnormal returns for shareholders. On the days before and after the announcement $(\mathrm{t}=-1$ and $\mathrm{t}=+1$ ), average abnormal returns amount to about $0.8 \%$. These returns are significant at the .01 ( $\mathrm{t}$-test) and .05 level (Corrado-Test). On the announcement day $(\mathrm{t}=0)$, an average abnormal return of $11.94 \%$ is earned, also highly significant ( $\mathrm{t}$-value $=55.42)$. Dependent on the time of the day when the buyout information reaches the capital market, the day of the release as well as the following day can be the actual announcement day. Since this is not known for most buyouts, the period from $\mathrm{t}=0$ to $\mathrm{t}=+1$ - and therefore the two-day CAR of $12.75 \%$ (t-value 41.84) - should be considered the announcement period return. From the ratio of positive to negative abnormal returns on day 0 , it is obvious that the announcement returns are not due to individual outliers.

In addition to the high abnormal returns on the announcement day, table IV shows significant returns prior to this date in some cases. For example, ARs for the days $t=-4$, $\mathrm{t}=-9, \mathrm{t}=-12$ and $\mathrm{t}=-15$ amount to $0.47 \%, 1.33 \%, 0.46 \%$ and $0.46 \%$, respectively (all significant at the 0.05 level). These abnormal returns prior to the actual announcement day can be explained by a possible leakage of information. ${ }^{19}$ There may, for example, be rumours about an upcoming LBO that already affect prices. With respect to the extraordinary high ARs in the announcement period $(\mathrm{t}=0 ; \mathrm{t}=+1)$ and the number of positive and negative returns, however, it can be concluded that information for most buyout offers becomes available to market participants only on the announcement day. In the period following the announcement, no significant abnormal returns can be observed. This suggests that all expected gains from the LBO are fully captured by the capital market only a few days after the announcement of 
the first bid. Therefore, this finding also provides evidence for the semi-strong market efficiency in European capital markets as defined by FAMA (1970 and 1991).

Furthermore, as can be seen in table $\mathrm{V}$, the cumulative abnormal returns over different event windows show significant abnormal returns.

\section{[Insert table V about here]}

Regarding the alternative methods of calculating the abnormal returns no differences between the constant mean return model and the market model could be detected. As shown in table $\mathrm{V}$ and figure $\mathrm{I}$, the average cumulative abnormal returns are very close to each other and do also have comparable levels of significance. For example, the returns over the period $[-1 ;+1]$ are $13.60 \%$ for the market model and $13.61 \%$ for the constant mean model and over the period $[-5 ;+5]$, the returns are $15.77 \%$ and $15.89 \%$ respectively.

\section{[Insert figure I about here]}

Another robustness check was carried out in order to investigate the abnormal returns in our sample. The abnormal returns were computed by subtracting the average return of the industry peer group ${ }^{20}$ on each event day from the realized return of the LBO target. This "peer group event study" is justified by the fact that a company's returns are closely correlated with the returns of its industry competitors. LANG and STULTZ (1992) were the first who compared a company's abnormal returns with the abnormal returns of its industry peer group on the announcement day. ${ }^{21}$ The results from this alternative approach confirm our previous findings. ${ }^{22}$

In conclusion, this study for the European capital market shows high and significant abnormal returns for pre-LBO shareholders of the LBO targets. The magnitude of the CARs lies in the range of values obtained in previous studies for the US market. 


\section{Results Of The Cross-Sectional Analysis}

Using the method of Ordinary Least Squares (OLS) we analyse the influence of the different determinants presented in Section II by means of the following general empirical model:

$$
\begin{aligned}
\mathrm{CAR}_{(-1,+1) \mathrm{i}}= & \mathrm{c}_{0}+\mathrm{c}_{1} F C F_{i}+\mathrm{c}_{2} \text { monitoring }_{i}+\mathrm{c}_{3} \text { stake }_{i}+\mathrm{c}_{4} \text { stake }_{i}{ }_{i}+\mathrm{c}_{5} \text { law }_{i}+\mathrm{c}_{6} \text { ADR } \\
& + \\
& +\mathrm{c}_{7} \text { size }_{i}+\mathrm{c}_{8} \text { price }_{i}+\mathrm{c}_{9} P / E_{i}+\mathrm{c}_{10} \text { contested }_{i}+\text { yeardummies }+ \\
& \text { countrydummies }+\mathrm{e}_{\mathrm{i}},
\end{aligned}
$$

where $\operatorname{CAR}_{(-1,+1) \mathrm{i}}$ is the 3 -day ${ }^{23}$ cumulated abnormal return for company $i$ and $\mathrm{e}_{\mathrm{i}}$ is the error term. T-statistics are based upon White heteroscedasticity-consistent standard errors. ${ }^{24}$ There is no sign of multicollinearity between the explanatory variables. ${ }^{25}$

As a robustness check we employ three variations of the original design. Model II shows the regression of the CARs of another event window $[0 ;+5]$ on the possible explanatory variables. Models III and IV are both restricted models of models I and II in which insignificant variables of the first two models and the year and time dummies are excluded. The results can be seen in table VI:

\section{[Insert table VI about here]}

The results support our hypothesis that corporate governance issues help to explain shareholder wealth gains in European LBO transactions. First, as hypothesized, the corporate governance regime has a negative and significant (at the 0.01-, 0.05- and 0.10-level) influence on the abnormal stock returns initiated by the announcement of an LBO transaction. The significant ADR variable implies that a poor protection of minority shareholders' rights can serve as an explanation for the wealth created for pre-LBO shareholders.

Second, the agency cost theory - mitigation of agency cost through closer monitoring - is further supported by the fact that, as hypothesized, the coefficient of the variable monitoring is significant (at the 0.05- or 0.10-level) and positive in all regressions. This is consistent with the hypothesis that as a result of an atomistic shareholder structure, management is not sufficiently controlled by its shareholders. Therefore, the stock price reaction is higher for companies with scattered shareholdings and thus a greater potential for efficiency 
improvements due to a more sophisticated and closer monitoring by the private equity investor.

Third, as predicted, the variable $P / E$ has a statistically significant (at the $0.05-$ or 0.10 level) and negative coefficient in all regressions. This finding implies that a company with profound agency-conflicts is undervalued compared to its peers that do not suffer from these problems. However, the undervaluation reflected by the $\mathrm{P} / \mathrm{E}$-ratio could also be related to an inadequate market valuation or information asymmetries assuming that peers are correctly valued and show no information asymmetries. These interpretations are further supported by the results for the variable price, which is significant (at the 0.05 -level or better) and negative in all equations.

Fourth, the regression results show insignificant coefficients for the variables $F C F$, stake, stake $^{2}$, law, contested and size. The insignificant law variable indicates that there is no significant difference between the abnormal returns in Continental Europe and the UK. Furthermore, the firm's FCFs prior to the going private transaction fail to explain the high abnormal returns observed in leveraged buyouts. Finally, the coefficients of all explanatory variables remain nearly unchanged when including time and country dummies.

The Wald-Coefficient test is used to investigate whether the insignificant coefficients in models one and two are also jointly insignificant. The high p-values of 0.812 and 0.818 indicate that the null hypothesis that all insignificant coefficients are equal to zero cannot be rejected in both models. We therefore estimate two restricted models (models 3 and 4) where only the significant variables of model one and two are included. The results confirm our previous findings.

One potential problem is that the period over which the price variable is calculated overlaps with the estimation window of the event study. This overlap could bias the results. Therefore, we estimated an additional regression using the CARs from the "peer group event study" as dependent variable. In this alternative approach, the abnormal returns are obtained by subtracting the peer group returns from the event window returns. Thus, no estimation window is needed. The results from these specifications are qualitatively and quantitatively similar to the findings presented above. ${ }^{26}$ 


\section{Conclusions}

The increasing number of LBOs in Europe has recently initiated several empirical examinations of the wealth gains associated with the buyout announcements (e.g. WEIR, LAING and WRIGHT 2005a or RENNEBOOG, SIMONS and WRIGHT 2005). These studies confirm previous evidence for the US, finding high premiums and significant abnormal returns in UK LBOs.

In order to gain deeper insights into the wealth effects of LBOs we therefore investigate a sample of 115 European leveraged going private transactions. Thus, we are able to examine whether institutional differences across countries have an influence on shareholder gains. Our results indicate that the pre-LBO quality of corporate governance mechanisms explain the magnitude of abnormal returns. On a macro level, we find that shareholder gains are larger in countries that have comparatively weaker protection for minority shareholders' rights and interests. On a firm level, companies with a high free float and dispersed shareholdings show (on average) higher announcement returns, meaning that the organizational changes inherent with the leveraged buyout (better monitoring and incentive alignment) create value in these companies. Other firm level findings confirm previous evidence on the UK and the US. Companies that are undervalued compared to a peer group of market-listed firms exhibit higher abnormal returns. In addition, announcement returns are higher for firms with a poor stock market performance prior to the buyout. 
${ }^{1}$ See TIROLE (2006).

${ }^{2}$ See HANDELSBLATT Nr. 149, page 29, 4th of August 2000.

${ }^{3}$ The event window contains 61 days ( 30 days before and 30 days after the event day 0 ).

${ }^{4}$ The premium is defined as the differential between the offer price and the current stock price (before the announcement).

${ }^{5}$ This success probability depends for example on the willingness of the shareholders to accept the tender offer.

${ }^{6}$ Although shareholdings below $5 \%$ have to be declared in the UK, we applied the $5 \%$ threshold to all countries in order to get consistent results (e.g. the German regulation defines the threshold as $5 \%$ and therefore it is not possible to get information on shareholdings below $5 \%)$.

${ }^{7}$ E.g. the definition of the Deutsche Börse AG.

${ }^{8}$ However, the evidence is mixed with LODERER and MARTIN (1997) and AGRAWAL and KNOEBER (1996) finding no relationship between managerial ownership and performance.

${ }^{9}$ A detailed summary of the ADR-Index is presented in LA PORTA et al. (1998), pp.11301131.

${ }^{10}$ In this context, the "efficient market" is defined as a market where all historical and publicly available information about future prospects is incorporated in the share price.

${ }^{11}$ See Ross Johnson (former CEO of RJR Nabisco, which has undergone the largest LBO in history) after a one-year decline of the stock price: "It's plain as the nose on your face that this company is wildly undervalued... Diversification is not working. We are sitting on food assets that are worth twenty-two, twenty-five times earnings and we trade at nine times earnings, because we're still seen as a tobacco company...The only way to recognize these values, I believe, is through a leveraged buyout." BURROUGH and HELYAR (1990).

12 TRAVLOS and CORNETT (1993) for instance find that in a cross-sectional regression against abnormal shareholder returns, the relative $\mathrm{P} / \mathrm{E}$ ratio is highly significant and conclude: "This finding is consistent with the joint hypothesis that the more severe the agency problems within the going private firms, the lower the relative $\mathrm{P} / \mathrm{E}$ ratio, and that the lower this ratio, the larger the room for improvement."

${ }^{13}$ Based on the composition of the EU in Dec. 2002.

${ }^{14}$ HALPERN, KIESCHNICK and ROTENBERG (1999) also use this criterion in order to identify pure LBO transactions. Here, debt financing includes all cash interest bearing debt or debt-like tranches, such as Senior Debt, Mezzanine Notes and Bridge Loans. They do not include debt-like tranches sponsored by the private equity investor, such as shareholder loans or Payment in Kind (PIK) notes.

${ }^{15}$ The balance sheet data of the three full financial years prior to the announcement date of the buyout is used. In some cases, the relevant currency within the peer Group differs. Therefore, we correct these differences by converting the different rates into one currency using the official exchange rate.

${ }^{16}$ The event study closely follows the research design of BROWN and WARNER (1985).

${ }^{17}$ For a detailed description of the Dow Jones STOXX 600 index see www.stoxx.com.

${ }^{18}$ See CORRADO (1989) for details.

${ }^{19}$ We cross-checked whether other firm relevant events (e.g. earnings announcement) occurred during the event window. No such events could be detected for the companies causing these significant abnormal returns before the announcement.

${ }^{20}$ Due to a lack of available data the peer group's size was reduced for some companies.

${ }^{21}$ LANG and STULTZ (1992) investigated the abnormal returns in the context of bankruptcy announcements. 
${ }^{22}$ Average cumulative returns based on the "peer group event study" (event window size in parentheses): $11.21 \%[0], 12.69 \%[-1 ;+1], 14.92 \%[-5 ;+5], 17.37 \%[-15 ;+15], 22.78 \%$ [$30 ;+30]$.

${ }^{23}$ The regression results are robust to variations of the event window size. Results for the $\mathrm{CAR}_{(0,+5) \mathrm{i}}$ are also presented in the following.

${ }^{24}$ Tests for heteroscedasticity are conducted using the White Heteroscedasticity Test (without cross-terms). The test statistics of models one and two (57.34 and 46.22) lie above the 0.05critical Chi-Square values.

${ }^{25}$ The absence of multicollinearity can be supported by the finding that there are no high pairwise correlations among the independent variables. The highest correlation coefficient (0.4752 ) is observed between the variables price and ADR.

${ }^{26}$ The coefficients of $A D R, P / E$, price and monitoring are significant at the 0.05 -level. 


\section{LITERATURE}

ADMATI, A., P. PFLEIDER, and J. ZECHNER (1994): "Large Shareholder Activism, Risk Sharing and Financial Market Equilibrium", Journal of Political Economy 102, pp. 1097-1130.

AGRAWAL, A. and C. KNOEBER (1996): "Firm Performance and Mechanisms to Control Agency Problems Between Managers and Shareholders", Journal of Financial and Quantitative Analysis 31, pp. 377-397.

AMIHUD, Y. (1989): "Leveraged Management Buyouts and Shareholders' Wealth", in: Amihud Y. (Editor), Leveraged Management Buyouts, Homewood, Ill., pp. 3-34.

BEINER, S., W. DROBETZ, M. SCHMID and H. ZIMMERMANN (2006): “An integrated framework of corporate governance and firm value", European Financial Management 12 , pp. $249-283$.

BROWN, S. J. and J. B. WARNER (1985): "Using Daily Stock returns: The case of event studies", Journal of Financial Economics 14(1), pp. 3-31.

BURROUGH, B. and J. HELYAR (1990): "Barbarians at the Gate - The Fall of RJR Nabisco", New York, NY, HarperCollins Publishers.

CMBOR (2005) Centre for Management Buy-Out Research Quarterly Review, Summer, Nottingham University Business School.

CORRADO, C.J. (1989): “A Nonparametric Test for Abnormal Security-Price Performance in Event Studies", Journal of Financial Economics 23(2), pp. 385-395.

DE ANGELO, H., L. DE ANGELO and E. M. RICE (1984): "Going Private: Minority Freeze-outs and Stockholder Wealth", Journal of Law and Economics 27(2), pp. 367401.

DE LONG, B.J., A. SHLEIFER, L. H. SUMMERS and R. J. WALDMANN (1990): "Noise Trader Risk in Financial Markets", Journal of Political Economy 98(4), pp. 703-738.

FACCIO, M and L.H.P. LANG (2002): "The ultimate ownership of Western European corporations", Journal of Financial Economics 65(3), pp. 365-395.

FAMA, E. F. (1970): "Efficient capital markets: A review of theory and empirical work", Journal of Finance 25(2), pp. 383-417. 
FAMA, E. F. (1991): “Efficient Capital Markets II”, Journal of Finance 46(5), pp. 1575-1617.

FRANKS, J. and C. MAYER (1990): "Capital markets and corporate control: a study of France, Germany and the UK", Economic Policy 4(10), pp. 189-231.

GRAMMATIKOS, T. and I. SWARY (1986): "Incentives for public firms to go private: Superior information or organizational efficiency", Working Paper.

GROSSMAN, S. J. and O. HART (1980): "Takeover bids, the free-rider problem, and the theory of the corporation", Bell Journal of Economics 11(1), pp. 42-64.

HALPERN, P., R. KIESCHNICK and W. ROTENBERG (1999): "On the Heterogenity of Leveraged Going Private Transactions", The Review of Financial Studies 12(2), pp. 281-309.

HANDELSBLATT (4th of August 2000): „Schon 20 Firmen in diesem Jahr von britischen Kurszetteln verschwunden“ 149, p.29.

HITE, G. L. and M. R. VETSUYPENS (1989): "Management Buyouts of Divisions and Shareholder Wealth", Journal of Finance 44(4), pp. 953-971.

JENSEN, M. and W. MECKLING (1976): "Theory of the Firm: Managerial behavior, agency costs and ownership structure”, Journal of Financial Economics 3(4), pp. 305-360.

JENSEN, M. and K. MURPHY (1990): "Performance Pay and Top-Management Incentives", Journal of Political Economy 98(2), pp. 225-264.

JENSEN, M. (1986): “Agency Costs of Free Cash Flow, Corporate Finance and Takeovers", American Economic Review 76(2), pp. 323-329.

JENSEN, M. (1989): "Eclipse of the Public Corporation", Harvard Business Review 67(5), pp. 61-74.

KAPLAN, S. N. (1989): "The Effects of Management Buyouts on Operating Performance and Value", Journal of Financial Economics 24(2), pp. 217-254.

LANG, L.H.P. and R.M. STULZ (1992): “Contagion and competitive intra-industry effects of bankruptcy announcements: An Empirical Analysis", Journal of Financial Economics 32(1), pp. 45-60. 
LA PORTA, R., R. LOPEZ-DE-SILANES, A. SHLEIFER and R.VISHNY (1998): "Law and Finance", Journal of Political Economy 106(6), pp. 1113-1155.

LEE, C.I., S. ROSENSTEIN, N. RANGAN and W.N. DAVIDSON (1992): "Board composition and shareholder wealth: the case of management buyouts", Financial Management 21(1), pp. 58-72.

LEHN, K. and A. POULSEN (1988): "Leveraged Buyouts: Wealth created or wealth redistributed", in: Murray Weidenbaum and Kenneth Chilton, Public Policy towards Corporate Takeovers, New Brunswick, NJ.

LEHN, K. and A. POULSEN (1989): "Free Cash Flow and Stockholder Gains in Going Private Transactions", Journal of Finance 44(3), pp. 771-787.

LODERER, C. and K. MARTIN (1997): "Executive stock ownership and performance: Tracking faint traces", Journal of Financial Economics 45, pp. 223-255.

LOWENSTEIN, L. (1985): “Management buyouts”, Columbia Law Review 85(4), pp. 730784.

MARAIS, L., K. SCHIPPER and A. SMITH (1989): "Wealth Effects of Going Private for Senior Securities”, Journal of Financial Economics 23(1), pp. 155-191.

MEHRAN, H., (1995): "Executive compensation structure, ownership, and firm performance", Journal of Financial Economics Vol. 38, pp. 163-184.

MORCK, R, SHLEIFER, A. and R.W. VISHNY (1988): "Management ownership and market valuation: An empirical analysis", Journal of Financial Economics 20, pp. 293 315 .

MCCONNELL, J. and H. SERVAES (1990): “Additional Evidence on Equity Ownership and Corporate Value", Journal of Financial Economics 27, pp. 595-613.

OPLER, T. and TITMAN, S. (1993): “The Determination of Leveraged Buy-out Activity: Free Cash Flow vs Financial Distress Costs”, Journal of Finance 48, pp. 1985-1999.

PEASNELL, K., P. POPE, and S. YOUNG (2003): "Managerial Equity Ownership and the Demand for Outside Directors", European Financial Management 9, pp. 231-250. 
RENNEBOOG, L., T. SIMONS and M. WRIGHT (2005): "Leveraged Public to Private Transactions in the UK", Working Paper 78/2005, (European Corporate Governance Institute).

SHLEIFER, A. and R.W VISHNY (1986): "Large Shareholders and Corporate Control", Journal of Political Economy 94, pp. 461-488.

STEWART, G. B. and D. M. GLASSMAN (1988): "The Motives and Methods of Corporate Restructuring: Part II.”, Journal of Applied Corporate Finance 1, pp.79-88.

TIROLE, J. (2006): “The Theory of Corporate Finance”, University Presses of CA, Berkeley.

TRAVLOS, N.G. and M. M. CORNETT (1993): "Going Private Buyouts and Determinants of Shareholders 'Returns”, Journal of Accounting, Auditing \& Finance 8(1), pp. 1-30.

VAN DER GUCHT, L.M. and W.T. MOORE (1998): "Predicting the duration and reversal probability of leveraged buyouts", Journal of Empirical Finance 5(4), pp. 299-315.

WEIR, C., D LAING and P MCKNIGHT (2002): "Internal and External Governance Mechanisms: Their Impact on the Performance of Large UK Public Companies", Journal of Business Finance and Accounting 29, pp. 579-611.

WEIR, C., D. LAING and M. WRIGHT (2005a): "Incentive Effects, Monitoring Mechanisms and the Market for Corporate Control: An Analysis of the Factors Affecting Public to Private Transactions in the UK", Journal of Business Finance \& Accounting 32(5-6), pp. 909-943.

WEIR, C., D. LAING and M. WRIGHT (2005b): "Undervaluation, private information, agency costs and the decision to go private", Applied Financial Economics 15(13), pp. $947-961$.

www.stoxx.com 


\section{Table I}

\section{Cumulative Abnormal Returns in various empirical studies}

\begin{tabular}{lcc}
\hline $\begin{array}{c}\text { Author (Publishing Year and } \\
\text { Number of LBOs) }\end{array}$ & $\begin{array}{c}\text { Days before and after the first } \\
\text { announcement[0] }\end{array}$ & $\begin{array}{c}\text { Average cumulative abnormal } \\
\text { return }\end{array}$ \\
\hline $\begin{array}{l}\text { DeAngelo, DeAngelo, Rice } \\
(1984)(72)\end{array}$ & {$[-1 ;+1]$} & $22.27 \%$ \\
Grammatikos, Swary & {$[-40 ; 0]$} & $30.40 \%$ \\
$(1986)(131)$ & {$[-10 ; 0]$} & $14.04 \%$ \\
Lehn, Poulsen & {$[-1 ;+1]$} & $19.52 \%$ \\
$(1989)(263)$ & {$[-10 ;+10]$} & $16.30 \%$ \\
Kaplan & {$[-60 ; 0]$} & $19.90 \%$ \\
$(1989)(25)$ & {$[-20 ; 0]$} & $37.90 \%$ \\
Amihud & {$[-1 ; 0]$} & $19.60 \%$ \\
$(1989)(15)$ & {$[-1 ; 0]$} & $13.00 \%$ \\
Marais, Schipper, Smith & {$[-1 ; 0]$} & $17.84 \%$ \\
$(1989)(80)$ & {$[-10 ;+10]$} & $16.20 \%$ \\
Lee, Rosenstein, Rangan, & {$[-1 ;+1]$} & $19.89 \%$ \\
Davidson (1992)(50) & {$[-10 ;+10]$} & $15.60 \%$ \\
Travlos, Cornett & {$[-1 ; 0]$} & $20.20 \%$ \\
$(1993)(56)$ & {$[-40 ;+40]$} & $22.68 \%$ \\
Van der Gucht, Moore & & $29.28 \%$ \\
$(1998)(187)$ &
\end{tabular}




\section{Table II}

Number, average transaction value, median transaction value, sum of transaction values and of the sample LBOs by year (Panel A) and by country (Panel B)

Transaction Values are taken from the Bloomberg database

\begin{tabular}{|c|c|c|c|c|}
\hline \multicolumn{5}{|c|}{ Panel A } \\
\hline Numb & ber of LBOs & $\begin{array}{c}\text { Average of } \\
\text { transaction values } \\
\text { (in Mio. } € \text { ) }\end{array}$ & $\begin{array}{c}\text { Median transaction } \\
\text { value } \\
\text { (in Mio. } € \text { ) }\end{array}$ & $\begin{array}{c}\text { Sum of transaction } \\
\text { values } \\
\text { (in Mio. } € \text { ) }\end{array}$ \\
\hline 1997 & 3 & 116.2 & 151.3 & 348.5 \\
\hline 1998 & 13 & 408.6 & 122.1 & 5312 \\
\hline 1999 & 30 & 390.8 & 180.7 & $11,722.8$ \\
\hline 2000 & 23 & 444.2 & 474.6 & $10,217.5$ \\
\hline 2001 & 9 & 742.7 & 314.0 & $6,684.5$ \\
\hline 2002 & 12 & 621.7 & 266.7 & $7,459.8$ \\
\hline 2003 & 9 & 610.0 & 439.8 & $5,490.2$ \\
\hline 2004 & 9 & 668.3 & 641.3 & $6,014.9$ \\
\hline 2005 & 7 & 999.4 & 843.1 & $6,995.7$ \\
\hline $1997-2005$ & 115 & 523.9 & 251.5 & $60,245.8$ \\
\hline \multicolumn{5}{|c|}{ Panel B } \\
\hline Country & $\begin{array}{c}\text { Number of } \\
\text { LBOs }\end{array}$ & $\begin{array}{c}\text { Average of } \\
\text { transaction values } \\
\text { (in Mio. } € \text { ) }\end{array}$ & $\begin{array}{c}\text { Median transaction } \\
\text { value } \\
\text { (in Mio. } €)\end{array}$ & $\begin{array}{c}\text { Sum of transaction } \\
\text { values } \\
\text { (in Mio. } € \text { ) }\end{array}$ \\
\hline United Kingdom & 60 & 430.8 & 223.0 & $29,724.5$ \\
\hline Germany & 12 & 538.8 & 386.3 & $6,466.1$ \\
\hline France & 11 & 232.9 & 175.3 & $2,562.3$ \\
\hline Netherlands & 5 & 786.2 & 641.3 & $3,931.1$ \\
\hline Sweden & 5 & 445.6 & 355.4 & $2,227.9$ \\
\hline Denmark & 3 & $1,363.0$ & 215.9 & $4,089.1$ \\
\hline Finland & 3 & 436.7 & 88.2 & $1,310.1$ \\
\hline Ireland & 3 & $2,417.9$ & $3,013.7$ & $7,253.7$ \\
\hline Norway & 2 & 628.3 & 628.3 & $1,256.5$ \\
\hline Italy & 1 & 647.3 & 647.3 & 647.3 \\
\hline Spain & 1 & 777.2 & 777.2 & 777.2 \\
\hline Sum & 115 & 523.9 & 251.5 & $60,245.8$ \\
\hline
\end{tabular}




\section{Table III}

\section{Key Data of the sample LBOs}

The free cash flow definition is the same as in Lehn and Poulsen (1989). The free cash flows are then divided by the companies' sales of the same fiscal year. The free float (monitoring) is being determined by subtracting all shareholdings of investors with an interest of more than $5 \%$ of the share capital from the total share capital. The relative $P / E$-ratio is computed by dividing the company's $P / E$ ratio by the $P / E$-ratio of the industry peer-group. The company's share price performance (price) is defined as the ratio of the closing market price two months prior to the LBO announcement divided by the average price, measured over 500 trading days counting backwards from two months prior to the LBO announcement. In order to exclude market movements we divide this figure by the equivalent ratio of the Dow Jones 600 market index. We use a dummy variable (law) to test for the influence of shareholder protection with " 0 " for Continental Europe, a system based on civil law, and " 1 " representing the UK where the system is based on common law. The variable $A D R$ is based on the Anti-Director-Rights-Index (ADR-Index) developed by La Porta et al. (1998). The variable contested is a dummy that equals " 1 " if the successful LBO bid is a reaction to a previous buyout offer and " 0 " otherwise. Size is measured by the natural log of total assets. Managerial ownership (if larger than 5\%) is measured by the variable stake.

\begin{tabular}{lcccc}
\hline & Average & Stand. Deviation. & Median & Spectrum \\
\hline FCF & 0.070 & 0.142 & 0.063 & {$[-0.926 ; 0.504]$} \\
monitoring & 0.503 & 0.218 & 0.512 & {$[0 ; 0.939]$} \\
P/E & 0.897 & 0.672 & 0.681 & {$[0.109 ; 4.307]$} \\
price & 0.909 & 0.323 & 0.870 & {$[0.190 ; 1.807]$} \\
law & 0.522 & 0.502 & 1 & {$[0 ; 1]$} \\
ADR & 3.922 & 1.470 & 5 & {$[0 ; 5]$} \\
contested & 0.070 & 0.256 & 0 & {$[0 ; 1]$} \\
size & 12.259 & 1.518 & 12.290 & {$[8.698 ; 16.037]$} \\
stake & 0.086 & 0.158 & 0 & {$[0 ; 1]$} \\
stake $^{2}$ & 0.032 & 0.115 & 0 & {$[0 ; 1]$} \\
\hline
\end{tabular}




\section{Table IV}

\section{Daily average abnormal returns and cumulative average abnormal returns for the whole sample}

of 115 European LBOs based on the Market Model.

Column 1 lists a cut-out of the event window relative to the announcement day $(t=0)$, column 2 contains the daily average abnormal returns (ARs) for each event day. Columns 3 and 4 present the corresponding test statistics (t-Test and Corrado-Test). These statistics indicate whether the null hypothesis of zero abnormal return on a given day can be rejected or not. Cumulative daily average abnormal returns (CARs) are displayed in column 5, while column 6 shows the ratio of positive and negative abnormal returns.

\begin{tabular}{|c|c|c|c|c|c|}
\hline $\begin{array}{l}\text { Day } \\
\text { relative to the } \\
\text { announcement }\end{array}$ & $\begin{array}{l}\text { Daily average } \\
\text { abnormal return } \\
\text { (AR) in } \%\end{array}$ & t-value & $\begin{array}{l}\text { Corrado- test } \\
\text { statistic }\end{array}$ & $\begin{array}{c}\text { Cumulative daily } \\
\text { average abnormal } \\
\text { return } \\
\text { (CAR) in } \%\end{array}$ & $\begin{array}{l}\text { Positive: } \\
\text { Negative }\end{array}$ \\
\hline-15 & $0.46 \%$ & $2.14 *$ & 0.19 & $0.46 \%$ & $51: 64$ \\
\hline-14 & $0.18 \%$ & 0.82 & -0.05 & $0.64 \%$ & $52: 63$ \\
\hline-13 & $0.01 \%$ & 0.03 & 0.44 & $0.64 \%$ & $53: 52$ \\
\hline-12 & $0.46 \%$ & $2.13 *$ & 0.85 & $1.10 \%$ & $59: 56$ \\
\hline-11 & $0.34 \%$ & 1.60 & 0.57 & $1.45 \%$ & $57: 58$ \\
\hline-10 & $0.21 \%$ & 0.99 & 1.33 & $1.66 \%$ & $62: 53$ \\
\hline-9 & $1.33 \%$ & $6.15^{* *}$ & 1.26 & $2.99 \%$ & $62: 53$ \\
\hline-8 & $0.34 \%$ & 1.58 & 1.44 & $3.33 \%$ & $64: 51$ \\
\hline-7 & $0.03 \%$ & 0.14 & -0.44 & $3.36 \%$ & $48: 67$ \\
\hline-6 & $-0.09 \%$ & -0.44 & -0.93 & $3.27 \%$ & $43: 72$ \\
\hline-5 & $0.30 \%$ & 1.39 & 0.20 & $3.57 \%$ & $54: 61$ \\
\hline-4 & $0.47 \%$ & $2.20 *$ & 1.03 & $4.04 \%$ & $61: 54$ \\
\hline-3 & $0.19 \%$ & 0.89 & 1.97 & $4.23 \%$ & $66: 49$ \\
\hline-2 & $0.28 \%$ & 1.28 & 0.66 & $4.51 \%$ & $59: 56$ \\
\hline-1 & $0.84 \%$ & $3.92 * *$ & $2.10 *$ & $5.35 \%$ & $66: 49$ \\
\hline 0 & $11.94 \%$ & $55.42 * *$ & $10.72 * *$ & $17.30 \%$ & $102: 13$ \\
\hline 1 & $0.81 \%$ & $3.75^{* *}$ & $2.13 *$ & $18.10 \%$ & $59: 56$ \\
\hline 2 & $0.43 \%$ & 1.97 & 1.73 & $18.53 \%$ & $63: 52$ \\
\hline 3 & $0.04 \%$ & 0.17 & 0.78 & $18.57 \%$ & $59: 56$ \\
\hline 4 & $0.32 \%$ & 1.47 & -0.12 & $18.88 \%$ & $51: 64$ \\
\hline 5 & $0.15 \%$ & 0.70 & 1.38 & $19.03 \%$ & $52: 63$ \\
\hline 6 & $-0.03 \%$ & -0.15 & 0.22 & $19.00 \%$ & $52: 63$ \\
\hline 7 & $0.02 \%$ & 0.09 & 0.38 & $19.02 \%$ & $55: 60$ \\
\hline 8 & $0.03 \%$ & 0.14 & 0.16 & $19.05 \%$ & $51: 64$ \\
\hline 9 & $-0.08 \%$ & -0.35 & 0.43 & $18.97 \%$ & $56: 59$ \\
\hline 10 & $0.00 \%$ & 0.01 & 0.40 & $18.98 \%$ & $53: 62$ \\
\hline 11 & $-0.07 \%$ & -0.32 & -0.04 & $18.91 \%$ & $49: 66$ \\
\hline 12 & $0.08 \%$ & 0.37 & 0.25 & $18.98 \%$ & $52: 63$ \\
\hline 13 & $0.02 \%$ & 0.11 & 0.24 & $19.01 \%$ & $51: 64$ \\
\hline 14 & $0.06 \%$ & 0.29 & 0.74 & $19.07 \%$ & $57: 58$ \\
\hline 15 & $0.00 \%$ & 0.01 & -0.05 & $19.07 \%$ & $47: 68$ \\
\hline
\end{tabular}

*significant at the 0.05 level, **significant at the 0.01 level (two-tailed test) 


\section{Table V}

Average cumulative abnormal returns based on the market model and the constant mean return model using daily stock data

The following table displays CARs for different symmetric event windows around the event day $(\mathrm{t}=0)$ based on the market model and the constant mean return model.

\begin{tabular}{lcc}
\hline Event Window & $\begin{array}{c}\text { Market Model } \\
\text { CARs (t-value) }\end{array}$ & $\begin{array}{c}\text { Constant Mean Return Model } \\
\text { CARs (t-value) }\end{array}$ \\
\hline$[-1 ;+1]$ & $13.60 \%(36.43)$ & $13.61 \%(35.60)$ \\
{$[-5 ;+5]$} & $15.77 \%(22.06)$ & $15.89 \%(21.70)$ \\
{$[-15 ;+15]$} & $19.07 \%(15.90)$ & $19.32 \%(15.72)$ \\
{$[-30 ;+30]$} & $24.20 \%(14.38)$ & $24.33 \%(14.12)$ \\
\hline
\end{tabular}

\section{Figure I}

Average cumulative abnormal returns based on the Market Model and the Constant Mean Return Model

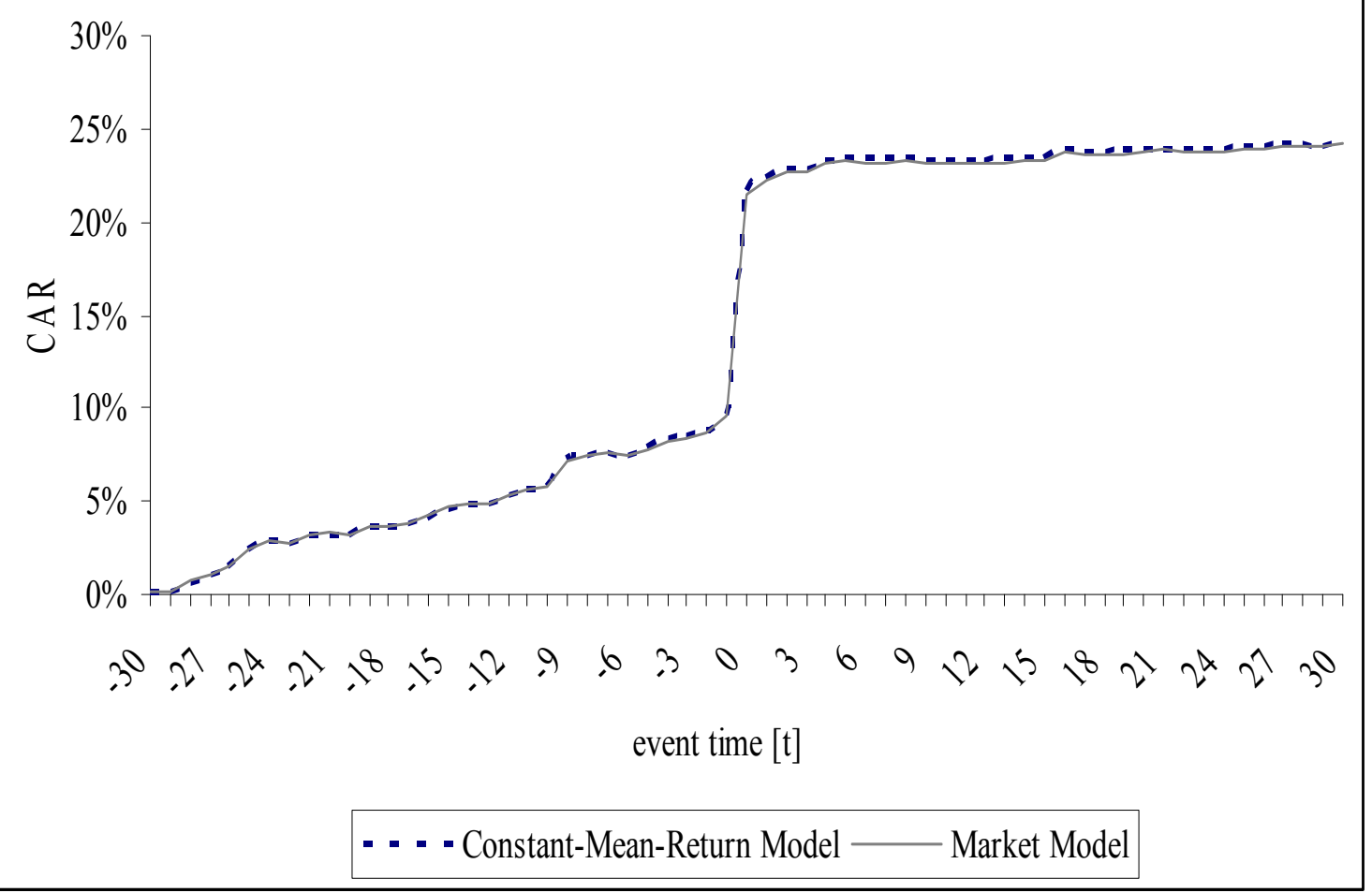




\section{Table VI}

\section{Estimated Coefficients and t-statistics (in parentheses) of the CAR regression}

OLS-regression of the CARs $[-1 ;+1]$ and CARs $[0 ;+5]$ on the variables $F C F$, monitoring, P/E, price, law, $A D R$, contested and size for 115 European LBOs between 1997-2005. T-statistics are based upon the White heteroscedasticity-consistent standard errors.

\begin{tabular}{|c|c|c|c|c|c|}
\hline $\begin{array}{c}\text { explanatory } \\
\text { variable }\end{array}$ & $\begin{array}{l}\text { expected } \\
\text { sign } \\
\end{array}$ & $\begin{array}{c}\text { model } 1 \\
\text { CARs }[-1 ;+1]\end{array}$ & $\begin{array}{c}\text { model } 2 \\
\text { CARs }[0 ;+5]\end{array}$ & $\begin{array}{c}\text { model } 3 \\
\text { CARs }[-1 ;+1]\end{array}$ & $\begin{array}{c}\text { model } 4 \\
\text { CARs }[0 ;+5]\end{array}$ \\
\hline Const. & & $0.171(1.15)$ & $0.559(3.91)^{* * *}$ & $0.238(3.86)^{* *}$ & $0.228(4.92)^{* *}$ \\
\hline$F C F$ & + & $-0.051(-0.60)$ & $-0.028(-0.26)$ & & \\
\hline monitoring & + & $0.121(1.86)^{*}$ & $0.132(1.89)^{*}$ & $0.149(2.32)^{* *}$ & $0.087(1.98)^{* *}$ \\
\hline$P / E$ & - & $-0.028(-1.70)^{*}$ & $-0.029(-2.10)^{* *}$ & $-0.028(-2.23)^{* *}$ & $-0.029(-2.31)^{* *}$ \\
\hline price & - & $-0.134(-2.50)^{* *}$ & $-0.144(-2.58)^{* *}$ & $-0.106(-2.83)^{* *}$ & $-0.127(-3.56)^{* * *}$ \\
\hline law & - & $0.005(0.14)$ & $0.002(0.62)$ & & \\
\hline$A D R$ & - & $-0.027(-2.30)^{* *}$ & $-0.040(-4.19)^{* * *}$ & $-0.014(-1.70)^{*}$ & $-0.014(-2.02) * *$ \\
\hline contested & + & $-0.051(-1.00)$ & $-0.020(-0.37)$ & & \\
\hline size & - & $0.011(1.26)$ & $-0.013(-1.43)$ & & \\
\hline stake & - & $-0.014(-0.09)$ & $0.088 \quad(0.56)$ & & \\
\hline $\operatorname{stake}^{2}$ & + & $0.022 \quad(0.10)$ & $-0.145(-0.75)$ & & \\
\hline Year dummies & & yes & yes & no & no \\
\hline Country dummies & & yes & yes & no & no \\
\hline $\mathrm{N}$ & & 115 & 115 & 115 & 115 \\
\hline $\mathrm{R}^{2}$ & & 0.36 & 0.37 & 0.18 & 0.19 \\
\hline F-statistic (p-Value) & & $1.69(0.03)$ & $2.93(0.02)$ & $6.04(0.00)$ & $6.46(0.00)$ \\
\hline
\end{tabular}

*significant at the 0.10 level, **significant at the 0.05 level, $* * *$ significant at the 0.01 level 